\title{
ARTICLE
}

\section{Spatial and temporal variations of coastal fish larvae, ectoparasites and oceanographic conditions off central Chile}

Variaciones espaciales y temporales de larvas de peces costeros, sus ectoparásitos, y condiciones oceanográficas frente a Chile central

\author{
Mauricio F. Landaeta ${ }^{1}$, Francisca Zavala-Muñoz ${ }^{1}$, Pámela Palacios-Fuentes ${ }^{1,2}$, \\ Claudia A. Bustos ${ }^{1}$, Mónica Alvarado-Niño ${ }^{3,4}$, Jaime Letelier ${ }^{3}$, \\ Mario A. Cáceres $^{5}$ and Gabriela Muñoz
}

\begin{abstract}
${ }^{1}$ Laboratorio de Ictioplancton (LABITI), Facultad de Ciencias del Mar y de Recursos Naturales, Universidad de Valparaíso, Avenida Borgoño 16344, Reñaca, Viña del Mar, Chile. mauricio.landaeta@uv.cl

${ }^{2}$ Programa de Doctorado en Ciencias Biológicas mención Ecología, Pontificia Universidad Católica de Chile, Avenida Portugal 49, Santiago de Chile, Chile

${ }^{3}$ Laboratorio de Oceanografía Física y Satelital (LOFISAT), Facultad de Ciencias del Mar y de Recursos Naturales, Universidad de Valparaíso, Avenida Borgoño 16344, Reñaca, Viña del Mar, Chile

${ }^{4}$ Programa de Magíster en Oceanografía, Universidad de Valparaíso, Facultad de Ciencias del Mar y de Recursos Naturales, Universidad de Valparaíso, Avenida Borgoño 16344, Reñaca, Viña del Mar, Chile

${ }^{5}$ Facultad de Ciencias del Mar y de Recursos Naturales, Universidad de Valparaíso, Avenida Borgoño 16344, Reñaca, Viña del Mar, Chile ${ }^{6}$ Laboratorio de Parasitología Marina, Facultad de Ciencias del Mar y de Recursos Naturales, Universidad de Valparaíso, Avenida Borgoño 16344, Reñaca, Viña del Mar, Chile
\end{abstract}

Resumen.- El objetivo de este estudio fue determinar la variación temporal de las condiciones oceanográficas, ictioplancton y sus ectoparásitos en aguas costeras marinas. Se realizaron 30 muestreos de ictioplancton entre el 11 de octubre 2012 y el 5 de junio 2014 a lo largo de una transecta desde 0,25 km hasta 4,5 km de la costa frente a Montemar, Bahía Valparaíso, Chile central. Se identificó un total de 5.553 larvas de peces, pertenecientes a 37 taxa. Las larvas de peces más abundantes originadas de desove pelágico fueron la sardina común Strangomera bentincki (abundancia relativa= $26,39 \%$ ), anchoveta Engraulis ringens $(8,94 \%)$, y el mictófido Hygophum bruuni $(7,72 \%)$; las especies más abundantes originadas de posturas bentónicas fueron la borrachilla Scartichthys viridis $(15,77 \%)$, el cachudito Hypsoblennius sordidus ( $8,27 \%)$ y el pejesapo Gobiesox marmoratus (7,06\%). Las larvas de peces más parasitadas provinieron de posturas bentónicas, los pejesapos G. marmoratus (prevalencia $=9,63 \%$ ) y Sicyases sanguineus $(0,54 \%)$, el tomollo Auchenionchus variolosus $(1,72 \%)$, y el trombollito de tres aletas Helcogrammoides cunninghami (3,28\%). La única especie con desove pelágico que presentó ectoparásitos fue el blanquillo Prolatilus jugularis $(0,57 \%)$. Las larvas de peces con ectoparásitos mostraron una disminución en abundancia con la distancia a la costa; S. bentincki, H. bruuni (desove pelágico) o S. viridis (postura bentónica) fueron más abundantes a 2,0 km de la costa. Los ectoparásitos fueron identificados como Trifur spp. (Copepoda: Pennellidae) y Caligus spp. (Copepoda: Caligidae), siendo los penélidos los más frecuentes ( 1 a 3 parásitos por larva). El 94 y $88 \%$ de los penélidos y calígidos, respectivamente, fue recolectado en la estación más costera. Durante los periodos de mayor prevalencia de ectoparásitos en las larvas de peces, el agua de mar estuvo verticalmente estratificada con una profundización a fines de otoño y un ascenso en verano de la picnoclina desde mar afuera hacia la costa. Por lo tanto, los resultados sugieren que las larvas de peces originadas de posturas bentónicas son parasitadas más frecuentemente y que las condiciones físicas de la columna de agua pueden favorecer tanto la retención costera como la infestación por ectoparásitos en las aguas más cercanas a la costa.

Palabras clave: Trifur sp., Caligus sp., pejesapo, gradientes horizontales de densidad, Chile central, Sudamérica

Abstract.- The objective of this study is to determine the temporal variation of oceanographic conditions, ichthyoplankton and their ectoparasites in nearshore marine waters. From October $11^{\text {th }} 2012$ to June $5^{\text {th }} 2014,30$ ichthyoplankton surveys were carried out along a cross-shelf transect from $0.25 \mathrm{~km}$ of the coastline to $4.50 \mathrm{~km}$ offshore off Montemar, Bahía Valparaíso, central Chile. We identified a total of 5,553 fish larvae, belonging to 37 taxa. The most abundant fish larvae with pelagic spawning were the common sardine Strangomera bentincki (relative abundance $=26.39 \%)$, the anchoveta Engraulis ringens (8.94\%), and the lanternfish Hygophum bruuni $(7.72 \%)$; whereas the most abundant species with benthic brooding were the blennies Scartichthys viridis (15.77\%), Hypsoblennius sordidus (8.27\%) and the clingfish Gobiesox marmoratus (7.06\%). The most parasitized fish larvae were from benthic brooding origin, namely the clingfishes $\mathrm{G}$. marmoratus (prevalence $=9.63 \%$ ) and Sicyases sanguineus (0.54\%), the kelpfish Auchenionchus variolosus (1.72\%), and triplefin blenny Helcogrammoides cunninghami (3.28\%). Only one species from pelagic spawning origin, the sandperch Prolatilus jugularis (0.57\%), had ectoparasites. The abundance of some larval fish species with ectoparasite decreased with distance to the shore; $\mathrm{S}$. bentincki, H. bruuni (pelagic spawning) or S. viridis (benthic brooding) were found to be more abundant at $2.0 \mathrm{~km}$ offshore. The ectoparasites were identified as Trifur spp. (Copepoda: Pennellidae) and Caligus spp. (Copepoda: Caligidae), with pennellids being the most frequent (1 to 3 parasites per larva). Ninety-four and $88 \%$ of pennellids and caligids, respectively, were collected in the nearshore station. During periods of high ectoparasite prevalence on fish larvae, seawater was vertically stratified with a cross-shelf deepening (late autumn) or shoaling (summer) of the pycnocline from offshore to nearshore. The results suggest that fish larvae with BB were more frequently parasitized and that physical conditions of the water column may contribute both to coastal retention of fish larvae as well as ectoparasite infestation in nearshore waters.

Key words: Trifur sp., Caligus sp., clingfish, horizontal density gradients, central Chile, South America 


\section{INTRODUCTION}

The variables that determine the structure of larval fish assemblages at a specific location include environmental features, acting at different spatial and temporal scales, and the behavioral responses of larvae to these factors (Carassou et al. 2008, Muhling et al. 2013, Flores-Coto et al. 2014). Physical processes such as mesoscale eddies (Sánchez-Velasco et al. 2013), frontal tide-mixing (Lee et al. 2005) and water column stratification (Bustos et al. 2008) may affect the composition and abundance of marine fish larvae. Additionally, scales of temporal variation of the ichthyoplankton include monthly (Kent et al. 2013), seasonal (Landaeta et al. 2008, Su et al. 2011), and multiyear fluctuations (e.g., ENSO-related, Landaeta et al. 2009). At spatial scales of less than a dozen of kilometers and temporal scales of less than 1 month, however, studies about the response of larval fish assemblages are scarce, particularly in temperate rocky reefs (Hernández-Miranda et al. 2003, Sabatés et al. 2003, Borges et al. 2007)

In nearshore rocky reef environments, larval fish stages of bottom-dwelling species may occur in high abundance and species richness (Hernández-Miranda et al. 2003, Kent et al. 2013). Given that local scale processes may affect dispersal of reef fish larvae, small-scale studies on larval spatial distributions can give information about possible retention mechanism near the habitat of the adults (Borges et al. 2007). Because most of the inshore species lay demersal eggs (i.e., Navarrete-Fernández et al. 2014) and their larvae dominate in the nearshore larval fish assemblages (Hernández-Miranda et al. 2003, Borges et al. 2007), it is expected that larval retention, and therefore self-recruitment, may increase due to locally produced larvae and/or transported from other reefs by alongshore currents.

In central Chile, recent studies have shown that several shallow-dwelling benthic species couple their hatching with the lunar cycle which may be associated with increased larval retention (e.g., the clingfish Gobiesox marmoratus, Contreras et al. 2013) or favor population connectivity (e.g., the triplefin Helcogrammoides chilensis, Palacios-Fuentes et al. 2014). These species are characterized for relatively long pelagic larval duration, ranging from 50 to 140 days (Plaza et al. 2013, Mansur et al. 2014), which pose a complex scenario for survival and nearshore recruitment of postlarvae. During this extended larval planktonic period, a series of ecological interactions take place in the water column, not only as predator-prey interactions, but also in the form of parasite-host interactions (Palacios-Fuentes et al. 2012, 2015). Ectoparasites, mostly copepods of the families Pennellidae and Caligidae (Muñoz et al. 2015), are recurrent in larval stages of benthic-brooding marine fishes from central Chile (Herrera 1984a, Palacios-Fuentes et al. 2015), causing significant reduction in the larval growth rates (Herrera 1990) and recent condition of fish larvae (PalaciosFuentes et al. 2012). However, it is no clear whether oceanographic processes mediate in the ectoparasitehost interactions in nearshore waters.

The aim of this study was to determine the spatiotemporal distribution patterns of fish larvae and their ectoparasites in a nearshore temperate area off Bahía Valparaíso, central Chile, and the relationship of them to oceanographic conditions and water column structure.

\section{Materials AND METHODS}

\section{FIELD AND LABORATORY WORK}

From October $11^{\text {th }} 2012$ to June $5^{\text {th }} 2014$, a series of 30 surveys were carried out during each season along a cross-shelf transect (Fig. 1) from $0.25 \mathrm{~km}$ offshore of the coastline to $4.50 \mathrm{~km}$ offshore off Montemar, Bahía de Valparaíso, central Chile. Five stations for CTD deployment and 3 stations for ichthyoplankton collection, were repeated 30 times. A Bongo net (60-cm diameter, 300 $\mu \mathrm{m}$ mesh) with a TSK flow meter, was obliquely towed for 10-15 min from $20 \mathrm{~m}$ depth to surface, at around 0.5,2 and $4 \mathrm{~km}$ offshore (Fig. 1). All samples were taken during the morning between 10 and $13 \mathrm{~h}$, at all tidal phases. Samples were preserved in 5\% formalin (with sodium borate), and within $24 \mathrm{~h}$ they were transferred to $96 \%$ ethanol.

All fish larvae were sorted and identified to the lowest possible taxonomic level under a stereomicroscope equipped with a digital camera. Identifications were based on descriptions given by Balbontín \& Pérez (1979, 1980), Pérez (1979, 1981), Balbontín \& Orellana (1983), Orellana \& Balbontín (1983), Herrera (1984b), Zúñiga \& Acuña (1992), Landaeta et al. (2006), and Herrera et al. (2007). Larvae were categorized, according to the reproductive strategy of the adults, either as pelagic spawners (PS), those who release their eggs (or larvae, in the case of rockfish Sebastes oculatus), or benthic brooders (BB), species that attach their eggs to benthic substrates (bottom, algae or nests) (Navarrete-Fernández et al. 2014). Additionally, all larvae were examined for ectoparasites. Parasitized larvae were placed into individual containers 


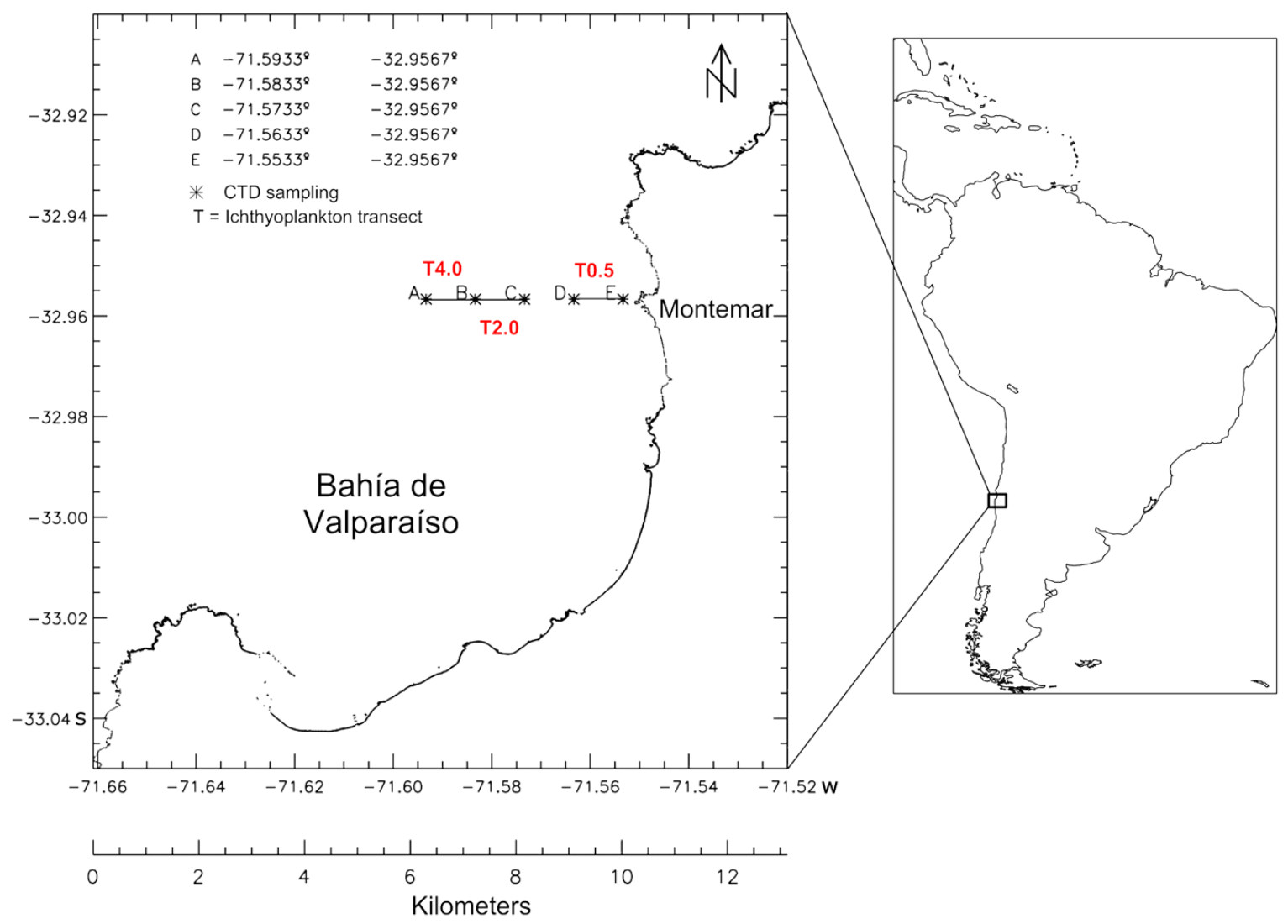

Figure 1. Location of the study site, indicating the position of CTD stations $\left(^{*}\right)$ and ichthyoplankton sampling transects (T) at $0.5,2.0$ and $4.0 \mathrm{~km}$ offshore Montemar, north Bahía Valparaíso, central Chile / Ubicación del sitio de estudio, indicando la posición de las estaciones de CTD (*) y las transectas de recolección de ictioplancton (T) a 0,5, 2,0 y 4,0 km de distancia de Montemar, al norte de la Bahía Valparaíso, Chile central

for further analysis. Each ectoparasite was identified to the lowest possible taxon based on structure of mouthparts and other appendages (Muñoz et al. 2015, Palacios-Fuentes et al. 2015).

\section{DATA ANALYSis}

The abundance of each larval fish species was expressed as number of larvae per $1000 \mathrm{~m}^{3}$. Larval abundance from PS and $\mathrm{BB}$ were compared utilizing Wilcoxon paired test, taking into account that larvae were extracted from the same sample unit. Moreover, the larval abundances in relation to distance from the shore were compared with Kruskal-Wallis tests for selected species.

To establish the differences in the abundance and composition of larval fish assemblages due to distance to shore and seasonality, a multivariate approach was applied separately for PS and BB larvae. The abundance of fish larvae was $\log (\mathrm{x}+1)$ transformed to enhance the contribution of less abundant larvae, and a Bray-Curtis similarity matrix was generated with these data. Similarities between samples were graphically represented by nonmetric multidimensional scaling (NMDS) ordination. The degree of correspondence between the distances among points was measured by a stress function. A two-way analysis of similarities (ANOSIM), which is analogous to a univariate analysis of variance, was utilized to determine the differences in ichthyoplankton composition among stations (0.5, 2 and $4 \mathrm{~km}$ from shore) and seasons (Spring 2012, 2013, Summer 2013, 2014, Autumn 2013, 2014 and Winter 2013). Pairwise ANOSIM comparisons were made between groups using 10,000 permutations.

The prevalence and intensity of ectoparasites were calculated separately for each larval fish taxon, based on the methods described by Bush et al. (1997). Comparison of the spatial distribution of ectoparasite families was carried out using contingence tables. All statistical analyses were carried out with Statistica 7.0 and Past 3.07. 
Table 1. Composition and abundance (ind. $1000 \mathrm{~m}^{-3}$ ) of fish larvae collected in nearshore waters off Montemar, central Chile between October 2012 and January 2014. SD= one standard deviation; PS= pelagic spawning; BB= benthic brooding / Composición y abundancia (ind. $1000 \mathrm{~m}^{-3}$ ) de larvas de peces recolectadas en aguas costeras frente a Montemar, Chile central, entre octubre 2012 y enero 2014 . SD= una desviación estándar; $\mathrm{PS}=$ desove pelágico; $\mathrm{BB}=$ desove bentónico

\begin{tabular}{|c|c|c|c|c|c|c|c|c|c|}
\hline Family & Species & $\begin{array}{c}\text { Type of } \\
\text { spawning }\end{array}$ & Total & $\%$ & Mean & SD & Median & Min & $\operatorname{Max}$ \\
\hline Clupeidae & Strangomera bentincki & PS & 8800.90 & 26.39 & 266.69 & 623.98 & 46.85 & 3.65 & 2867.30 \\
\hline Engraulidae & Engraulis ringens & PS & 2981.25 & 8.94 & 72.71 & 238.24 & 11.67 & 4.70 & 1493.73 \\
\hline \multirow{6}{*}{ Myctophidae } & Diaphus sp. & PS & 15.54 & 0.04 & 5.18 & 0.78 & 5.02 & 4.49 & 6.03 \\
\hline & Diogenichthys laternatus & PS & 25.91 & 0.07 & 12.95 & 2.71 & 12.95 & 11.04 & 14.87 \\
\hline & Hygophum bruuni & PS & 2574.93 & 7.72 & 42.21 & 100.21 & 10.55 & 3.38 & 694.36 \\
\hline & Lampanyctus iselinoides & PS & 354.25 & 1.06 & 11.43 & 13.32 & 6.81 & 3.38 & 71.22 \\
\hline & Lampanyctus sp1. & PS & 6.79 & 0.02 & 6.79 & - & 6.79 & 6.79 & 6.79 \\
\hline & Triphoturus oculeus & PS & 169.66 & 0.50 & 16.97 & 15.63 & 10.97 & 4.08 & 51.25 \\
\hline Merlucciidae & Merluccius gayi & PS & 296.19 & 0.88 & 37.02 & 39.83 & 20.73 & 5.39 & 120.30 \\
\hline Ophidiidae & Genypterus sp. & $\mathrm{BB}$ & 36.66 & 0.11 & 12.22 & 4.85 & 9.85 & 9.01 & 17.80 \\
\hline \multirow{2}{*}{ Gobiesocidae } & Gobiesox marmoratus & $\mathrm{BB}$ & 2353.31 & 7.05 & 47.07 & 124.95 & 11.73 & 3.68 & 780.02 \\
\hline & Sicyases sanguineus & $\mathrm{BB}$ & 1087.36 & 3.26 & 32.95 & 56.02 & 11.05 & 3.89 & 272.73 \\
\hline Atherinopsidae & Odontesthes regia & $\mathrm{BB}$ & 12.16 & 0.03 & 6.08 & 0.07 & 6.08 & 6.03 & 6.13 \\
\hline Syngnathidae & Leptonotus blainvilleanus & $\mathrm{BB}$ & 5.25 & 0.01 & 5.25 & - & 5.25 & 5.25 & 5.25 \\
\hline Sciaenidae & & PS & 24.37 & 0.07 & 6.09 & 1.84 & 5.26 & 5.02 & 8.83 \\
\hline Normanichthyidae & Normanichthys crockeri & PS & 129.70 & 0.38 & 16.21 & 12.89 & 12.63 & 5.02 & 40.10 \\
\hline Bovichthydae & Bovichthys chilensis & PS & 3.53 & 0.01 & 3.53 & - & 3.53 & 3.53 & 3.53 \\
\hline Sebastidae & Sebastes oculatus & PS & 1938.93 & 5.81 & 27.31 & 36.69 & 15.17 & 3.68 & 280.70 \\
\hline Kyphosidae & Girella laevifrons & PS & 525.92 & 1.57 & 30.94 & 30.08 & 20.23 & 3.89 & 97.15 \\
\hline Pomacentridae & Chromis crusma & $\mathrm{BB}$ & 521.01 & 1.56 & 26.05 & 39.89 & 6.96 & 3.89 & 140.19 \\
\hline \multirow{2}{*}{ Pinguipedidae } & Pinguipes chilensis & PS & 12.26 & 0.03 & 6.13 & 0.96 & 6.13 & 5.45 & 6.81 \\
\hline & Prolatilus jugularis & PS & 1134.65 & 3.40 & 51.57 & 86.33 & 21.89 & 4.96 & 381.83 \\
\hline \multirow{3}{*}{ Trypterygiidae } & Helcogrammoides chilensis & $\mathrm{BB}$ & 1027.41 & 3.08 & 25.06 & 41.88 & 9.23 & 3.38 & 202.32 \\
\hline & Helcogrammoides cunninghami & $\mathrm{BB}$ & 363.73 & 1.09 & 17.32 & 20.77 & 9.68 & 4.49 & 89.40 \\
\hline & Auchenionchus variolosus & $\mathrm{BB}$ & 312.12 & 0.93 & 9.75 & 9.73 & 6.73 & 3.34 & 49.09 \\
\hline \multirow[t]{2}{*}{ Labrisomidae } & Auchenionchus microcirris & $\mathrm{BB}$ & 22.08 & 0.06 & 7.36 & 6.51 & 3.68 & 3.53 & 14.87 \\
\hline & Auchenionchus crinitus & $\mathrm{BB}$ & 291.47 & 0.87 & 11.21 & 9.98 & 7.88 & 3.34 & 42.19 \\
\hline Clinidae & Myxodes spp. & $\mathrm{BB}$ & 13.53 & 0.04 & 6.76 & 4.36 & 6.76 & 3.68 & 9.85 \\
\hline Dactyloscopidae & Sindoscopus australis & $\mathrm{BB}$ & 87.56 & 0.26 & 7.96 & 4.97 & 6.03 & 3.53 & 21.09 \\
\hline \multirow{2}{*}{ Blenniidae } & Scartichthys viridis & $\mathrm{BB}$ & 5259.41 & 15.77 & 65.74 & 143.14 & 13.59 & 3.34 & 952.64 \\
\hline & Hypsoblennius sordidus & $\mathrm{BB}$ & 2758.09 & 8.27 & 30.65 & 47.73 & 16.59 & 3.53 & 301.13 \\
\hline \multirow[t]{2}{*}{ Stromateidae } & Stromateus stellatus & PS & 45.88 & 0.13 & 6.55 & 3.40 & 5.02 & 3.89 & 12.31 \\
\hline & Hippoglossina macrops & PS & 286.70 & 0.86 & 14.33 & 14.32 & 9.94 & 3.89 & 53.41 \\
\hline \multirow[t]{2}{*}{ Paralichthyidae } & Paralichthys adspersus & PS & 37.01 & 0.11 & 9.25 & 5.86 & 7.14 & 5.06 & 17.66 \\
\hline & Paralichthys microps & PS & 114.65 & 0.34 & 16.38 & 18.36 & 10.91 & 5.02 & 57.66 \\
\hline Unidentified larvae & & & 94.31 & 0.28 & 7.25 & 3.09 & 5.87 & 3.65 & 11.84 \\
\hline
\end{tabular}




\section{Results}

\section{LARVAL FISH ASSEMBLAGE IN NEARSHORE WATERS}

A total of 5553 fish larvae, belonging to 37 taxa were identified (Table 1). The most abundant fish larvae from pelagic spawning (PS) were the common sardine Strangomera bentincki $(26.39 \%)$, the anchoveta Engraulis ringens (8.94\%), and the lanternfish Hygophum bruuni $(7.72 \%)$. The larvae of the blennies Scartichthys viridis $(15.77 \%)$, Hypsoblennius sordidus $(8.27 \%)$ and the clingfish Gobiesox marmoratus (7.06\%) were the most abundant species with benthic brooding (BB).

Figure 2 shows the temporal variation in larvae from $\mathrm{PS}$ and $\mathrm{BB}$, at different distances from the shore. In the nearshore stations $(0.5$ and $2.0 \mathrm{~km}), \mathrm{BB}$ larvae were dominant almost throughout the sampling period, except late September 2013, when the PS S. bentincki larvae increased its abundance (to $70.2 \%$ ) (Figs. 2a, b). At 4.0 $\mathrm{km}$ offshore, BB larvae dominated from early October 2012 to late January 2013; after that, PS larvae dominated until June 2014 (Fig. 2c). However, the differences in the abundance of larvae from PS were not significant compared to those of $\mathrm{BB}$ (Wilcoxon test, $\mathrm{T}=1576, P=$ 0.271).

The multivariate analyses showed differences in the spatial and temporal variability of PS and BB fish larvae (Fig. 3). Larvae from PS did not show differences along the transect (global $\mathrm{R}=0.001, P=0.472$ ), but there were differences among seasons (global $\mathrm{R}=0.295, P=0.001$ ) (Table 2). On the other hand, larvae from BB showed significant spatial differences along the transect (global $\mathrm{R}=0.069, P=0.007$ ) as well as among seasons (global $\mathrm{R}=$ $0.168, P=0.001)$ (Table 2).

A significant decrease in abundance with distance to the shore was detected for the larvae of clingfish $G$. marmoratus $(\mathrm{H}=6.393, P=0.041)$ and the triplefin blenny H. cunninghami $(\mathrm{H}=8.647, P=0.013)$ (Fig. 4). Some fish species, such as clingfish $S$. sanguineus, kelpfish $A$. variolosus (BB) and sandperch $P$. jugularis (PS) were collected mainly in nearshore waters (Fig. 4), whereas $S$. bentincki, $H$. bruuni (PS) and $S$. viridis (BB) were found to be more abundant at $2.0 \mathrm{~km}$ offshore (Fig. 4). Due largely to the high variance, no significant differences were recorded among stations for these species ( $S$. sanguineus, $\mathrm{H}=1.061, P=0.588 ;$ A. variolosus, $\mathrm{H}=1.189, P=0.551 ; P$. jugularis, $\mathrm{H}=1.624, P=0.443 ; S$. bentincki, $\mathrm{H}=1.028, P=$ 0.597; H. bruuni, $\mathrm{H}=1.564, P=0.457 ; S$. viridis, $\mathrm{H}=1.367$, $P=0.504)$. a)

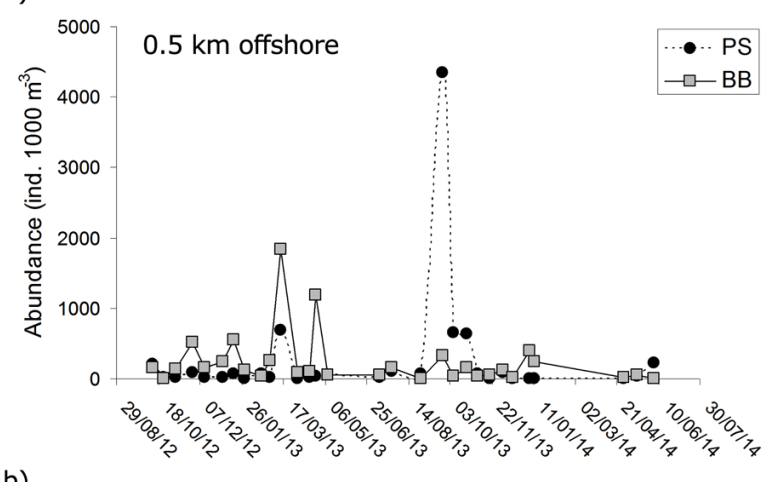

b)
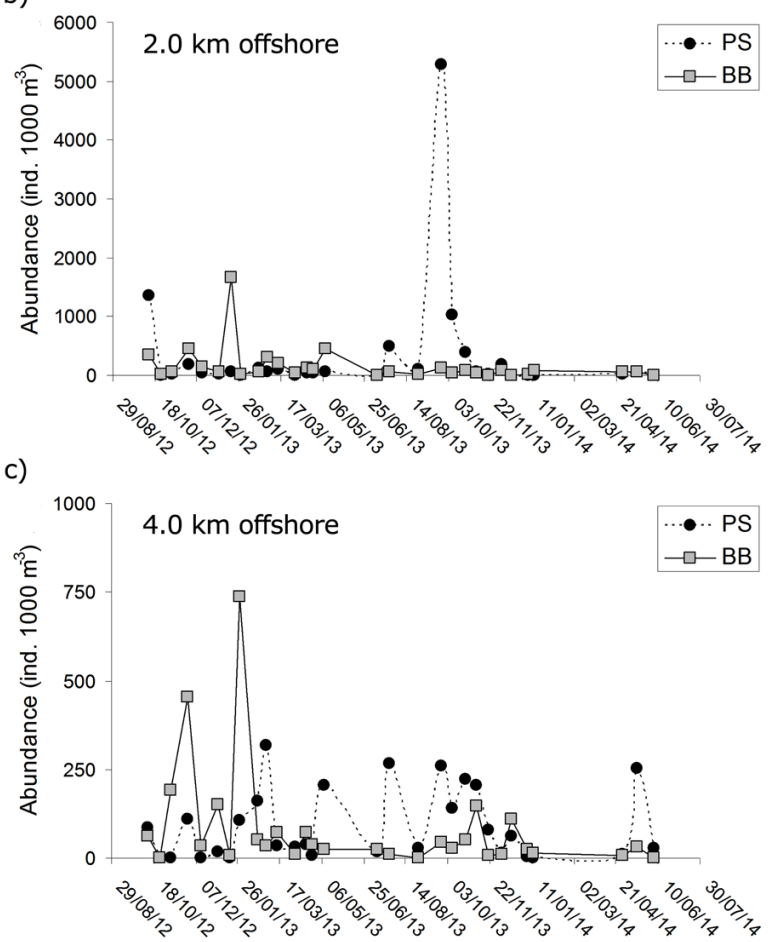

Figure 2. Temporal variation of standardized abundance (ind. 1000 $\mathrm{m}^{-3}$ ) of fish larvae from pelagic spawning (PS, black dots) and from benthic brooding (BB, grey squares) at different distances from shore, from October 2012 to June 2014 / Variación temporal de la abundancia estandarizada (ind. $1000 \mathrm{~m}^{-3}$ ) de las larvas de peces provenientes de desoves pelágicos (DP, círculos negros) y desoves bentónicos (DB, cuadrados grises) a diferentes distancias de la costa, desde octubre 2012 a junio 2014 
Figure 3. Ordination plots of nonmetric multidimensional scaling (NMDS) of ichthyoplankton with pelagic spawning (PS) and benthic brooding (BB). NM DS plots were done taking into account distance from shore (left panel) and sampling season (right panel) / Gráficos de ordenación de escalamiento no métrico multidimensional (NMDS) para el ictioplancton con desove pelágico (DP) y desove bentónico (DB). Los gráficos NMDS fueron realizados de acuerdo a la distancia de la costa (panel izquierdo) y la estación de muestreo (panel derecho)
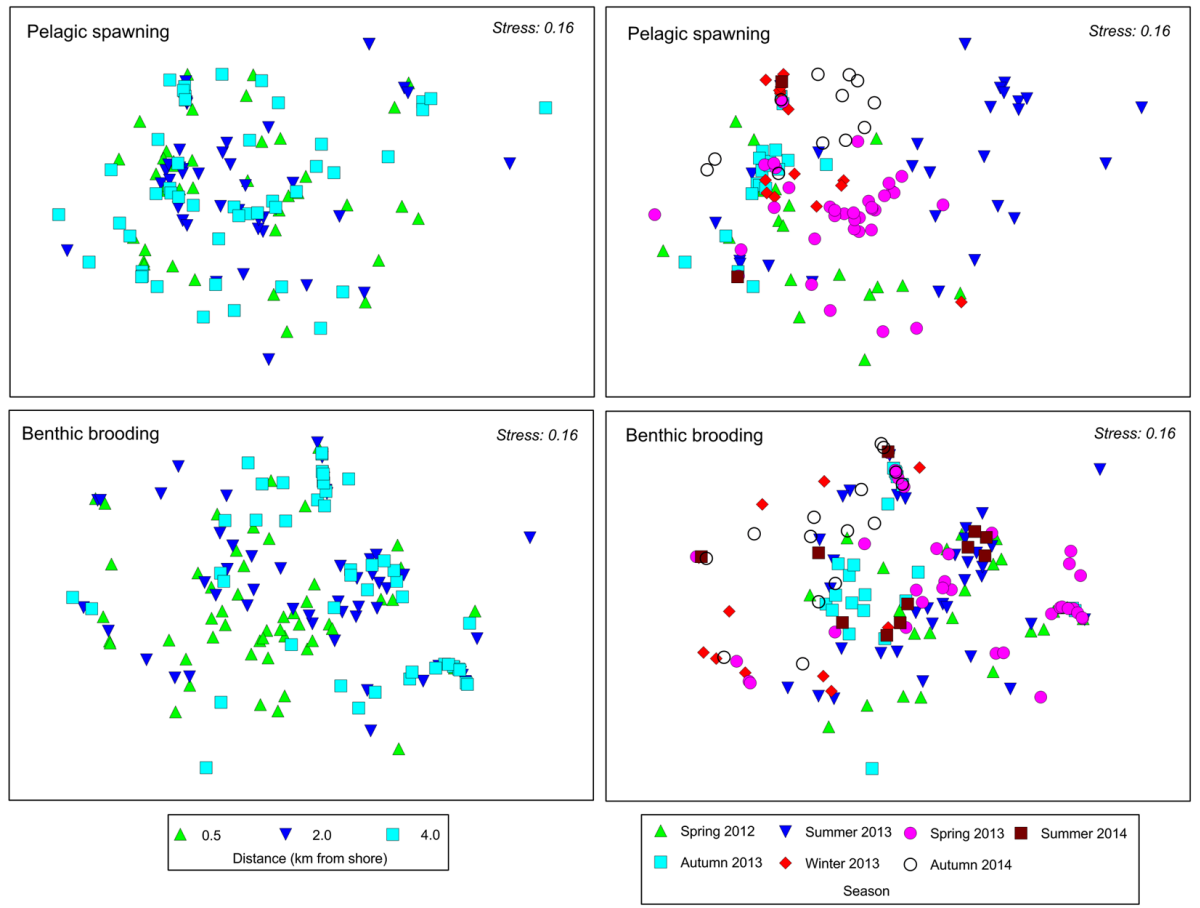

Table 2. Summary of results of two-way ANOSIM carried out with larvae from pelagic spawning (PS) and benthic brooding (BB), according to distance from shore and sampling season. Bold numbers indicate significant differences at $\mathbf{P}<\mathbf{0 . 0 5}$ / Resumen de los resultados del ANOSIM de dos vías llevado a cabo con larvas originadas de desoves pelágicos (PS) y crianza bentónica (BB), de acuerdo a la distancia a la costa y estación del año del muestreo. Los números en negrita indican diferencias significativas a $\mathrm{P}<0,05$

\begin{tabular}{|c|c|c|c|c|c|}
\hline & \multirow[t]{2}{*}{ Groups } & \multicolumn{2}{|c|}{$\begin{array}{c}\text { Pelagic } \\
\text { spawning }\end{array}$} & \multicolumn{2}{|c|}{$\begin{array}{l}\text { Benthic } \\
\text { brooding }\end{array}$} \\
\hline & & $\mathrm{R}$ & $P$ & $\mathrm{R}$ & $P$ \\
\hline \multirow[t]{3}{*}{ By distance } & $0.5 \mathrm{~km}, 2.0 \mathrm{~km}$ & 0.020 & 0.272 & 0.064 & 0.042 \\
\hline & $0.5 \mathrm{~km}, 4.0 \mathrm{~km}$ & 0.009 & 0.377 & 0.165 & 0.002 \\
\hline & $2.0 \mathrm{~km}, 4.0 \mathrm{~km}$ & -0.023 & 0.704 & -0.007 & 0.550 \\
\hline \multirow[t]{21}{*}{ By season } & Spring 2012, Summer 2013 & 0.313 & 0.001 & 0.049 & 0.127 \\
\hline & Spring 2012, Autumn 2013 & 0.226 & 0.001 & 0.224 & 0.001 \\
\hline & Spring 2012, Winter 2013 & 0.239 & 0.006 & 0.423 & 0.001 \\
\hline & Spring 2012, Spring 2013 & 0.149 & 0.058 & -0.010 & 0.559 \\
\hline & Spring 2012, Summer 2014 & 0.501 & 0.025 & 0.018 & 0.362 \\
\hline & Spring 2012, Autumn 2014 & 0.253 & 0.016 & 0.501 & 0.001 \\
\hline & Summer 2013, Autumn 2013 & 0.347 & 0.001 & -0.02 & 0.653 \\
\hline & Summer 2013, Winter 2013 & 0.370 & 0.001 & 0.225 & 0.017 \\
\hline & Summer 2013, Spring 2013 & 0.396 & 0.001 & 0.064 & 0.050 \\
\hline & Summer 2013, Summer 2014 & 0.392 & 0.042 & -0.196 & 0.991 \\
\hline & Summer 2013, Autumn 2014 & 0.272 & 0.003 & 0.171 & 0.013 \\
\hline & Autumn 2013, Winter 2013 & 0.272 & 0.003 & 0.244 & 0.009 \\
\hline & Autumn 2013, Spring 2013 & 0.275 & 0.001 & 0.163 & 0.009 \\
\hline & Autumn 2013, Summer 2014 & 0.131 & 0.321 & -0.086 & 0.816 \\
\hline & Autumn 2013, Autumn 2014 & 0.445 & 0.001 & 0.122 & 0.067 \\
\hline & Winter 2013, Spring 2013 & 0.260 & 0.001 & 0.193 & 0.022 \\
\hline & Winter 2013, Summer 2014 & 0.738 & 0.024 & 0.099 & 0.208 \\
\hline & Winter 2013, Autumn 2014 & 0.173 & 0.060 & 0.128 & 0.089 \\
\hline & Spring 2013, Summer 2014 & 0.427 & 0.028 & -0.072 & 0.768 \\
\hline & Spring 2013, Autumn 2014 & 0.374 & 0.001 & 0.281 & 0.001 \\
\hline & Summer 2014, Autumn 2014 & 0.982 & 0.036 & 0.165 & 0.075 \\
\hline
\end{tabular}



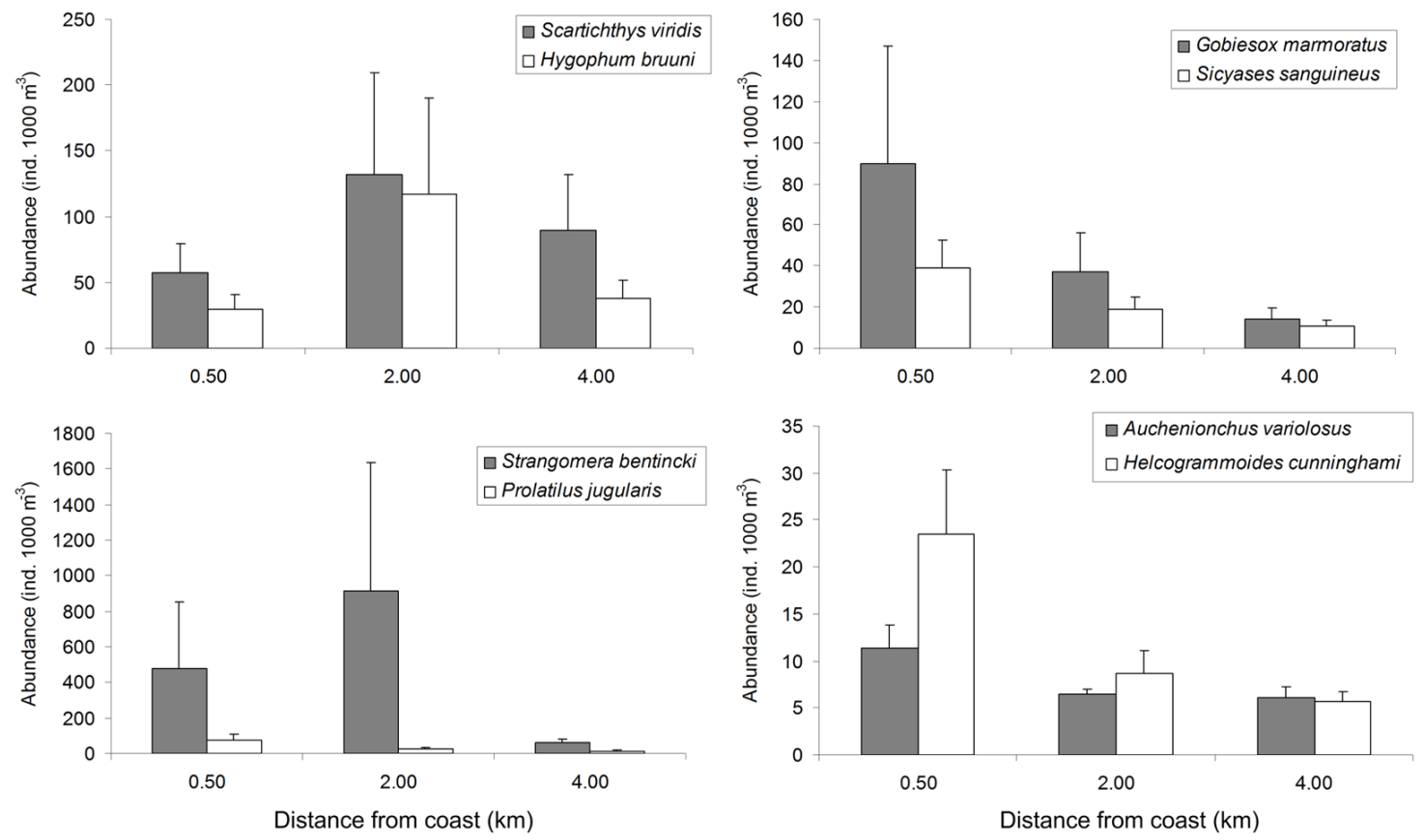

Figure 4. Cross-shelf distribution of fish larvae from Montemar, Bahía Valparaíso, central Chile. Bars correspond to one standard error / Distribución a lo ancho de la plataforma continental de larvas de peces de Montemar, Bahía Valparaíso, Chile central. Las barras corresponden a un error estándar

Table 3. Prevalence and intensity range of the 2 parasite families found on the larvae of 5 different species from nearshore waters of the coasts of Montemar, Bahía Valparaíso, central Chile / Prevalencia y rango de intensidad de las 2 familias de parásitos encontrados en las larvas de 5 diferentes especies de peces de aguas costeras de Montemar, Bahía Valparaíso, Chile central

\begin{tabular}{|c|c|c|c|c|c|c|}
\hline \multirow{2}{*}{ Taxa } & \multirow{2}{*}{$\begin{array}{l}\text { Sample } \\
\text { size (n) }\end{array}$} & \multirow{2}{*}{$\begin{array}{l}\text { Total density } \\
\text { (ind. } 1000 \mathrm{~m}^{-3} \text { ) }\end{array}$} & \multicolumn{2}{|c|}{ Pennellidae } & \multicolumn{2}{|c|}{ Caligidae } \\
\hline & & & Prevalence & Intensity & Prevalence & Intensity \\
\hline Auchenionchus variolosus & 58 & 312.12 & 1.724 & [1] & 1.724 & [1] \\
\hline Gobiesox marmoratus & 405 & 2353.31 & 9.630 & {$[1-3]$} & 4.938 & {$[1-2]$} \\
\hline Helcogrammoides cunninghami & 61 & 363.73 & 3.279 & {$[1]$} & & \\
\hline Sicyases sanguineus & 184 & 1087.36 & & & 0.543 & [1] \\
\hline Prolatilus jugularis & 176 & 1134.65 & 0.568 & [1] & & \\
\hline
\end{tabular}

\section{ECTOPARASITES OF FISH LARVAE}

The most parasitized fish larvae were from BB origin, particularly the clingfishes G. marmoratus $(9.63 \%)$ and Sicyases sanguineus (0.54\%), the kelpfish Auchenionchus variolosus $(1.72 \%)$, and the triplefin Helcogrammoides cunninghami (3.28\%) (Table 3). The larvae of only one species from PS origin, the sandperch Prolatilus jugularis $(0.57 \%)$, had ectoparasites.

A total of 74 ectoparasites were recovered from fish larvae. Seven morpho-species were determined, 2 belonging to families Pennellidae and 5 to Caligidae. They were identified as Trifur spp. (Copepoda: Pennellidae) and Caligus spp. (Copepoda: Caligidae). The most prevalent ectoparasites were pennellid copepods, with a range of 1 to 3 parasites per larvae (Table 3 ). Both ectoparasite families showed a similar spatial pattern $\left(\chi^{2}=\right.$ $0.815, P=0.665)$, as they were collected mainly in the nearshore station (94 and $88 \%$ for pennellids and caligids, respectively), decreasing exponentially offshore (Fig. 5a). Furthermore, pennellids and caligids on fish larvae 

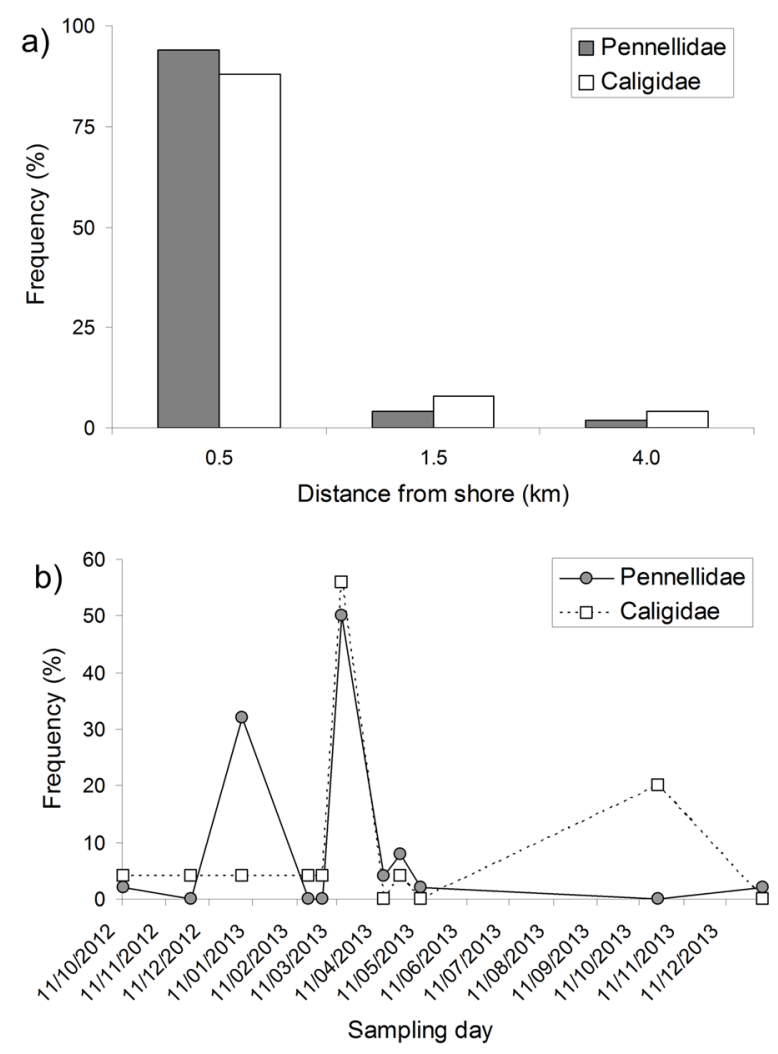

Figure 5. Distributions of ectoparasites of fish larvae from Montemar, Bahía Valparaíso, central Chile. a) Cross-shelf distribution of frequency (\%); b) Temporal variation of frequency (\%) / Distribución de ectoparásitos de larvas de peces de Montemar, Bahía Valparaíso, Chile central. a) frecuencias (\%) a lo ancho de la plataforma; b) variación temporal de las frecuencias (\%)

showed significant different temporal variability $\left(\chi^{2}=38.1\right.$, $P<0.001)$ between them. Pennellids were more frequent during summer and autumn, whereas caligids were more frequent during spring and summer. Specifically, they were found mainly during mid March 2013 (Fig. 5b); pennellids were also frequent during early January 2013, and caligids during late October 2013 (Fig. 5b). In summary, parasitism on fish larvae were more prevalent during summer, autumn and spring, and closer to the coast.

\section{Physical settings}

Cross-shelf vertical sections of temperature, salinity and density are shown in Figure 6 for selected sampling periods of austral mid- and late-summer, and early winter. During mid-summer, the water column was vertically stratified, with an offshore shoaling of the thermocline, from $\sim 20 \mathrm{~m}$ in the nearshore station to $\sim 8 \mathrm{~m}$ in the offshore location (Fig. 6). At around $3 \mathrm{~km}$ offshore and in subsurface waters (10 m depth) a tongue of relatively fresher water, probably originated from the Aconcagua River discharges, was evident. Both oceanographic features produced a pycnocline at depths between 10-20 m. On March 14, surface seawater temperature dropped to $13.5^{\circ} \mathrm{C}$, showing a weak thermocline at $5 \mathrm{~m}$ depth; during this period fresher waters $(<34.3)$ were found down to 20 $30 \mathrm{~m}$ depth cross-shelf, causing a shoaling of the pycnocline from $20 \mathrm{~m}$ at $2.5 \mathrm{~km}$ offshore to $8 \mathrm{~m}$ at $0.5 \mathrm{~km}$ offshore (Fig. 6). During early winter, the density vertical structure of the water column showed a similar pattern observed during mid-summer, but with lower temperatures and salinities; nearshore waters were dominated by fresher (<34.3) waters, producing a nearshore deepening of the pycnocline (isopycnal 25.9 units of sigma-t at $20-25 \mathrm{~m}$ depth, Fig. 6).

\section{Discussion}

The larval fish assemblage from coastal waters off Montemar, central Chile, showed spatial and temporal variability similar to that described by Hernández-Miranda et al. (2003), at a location $50 \mathrm{~km}$ south to our study site. Cross-shelf distributions of several larval fish taxa and their ectoparasites showed a clear inner-shelf pattern. Intertidal fish species with benthic eggs, like clingfishes and triplefins, are probably not affected by advective processes until they hatch, which reduces the chances of offshore transport. Additionally, hatching events may be synchronized with neap tides (i.e., during first quarter and/or third quarter moon), increasing coastal retention (i.e., G. marmoratus, Contreras et al. 2013) and potential ectoparasite infestation of fish larvae (Palacios-Fuentes et al. 2015). A similar cross-shelf pattern has been reported for larval tripterygiids in the St. Lucia Estuary, southeast Africa (Harris et al. 1999), and for larval tripterygiids and blennies in the coast of Portugal (Borges et al. 2007).

On the other hand, dispersive events of early larvae from BB can occur. Hatching can take place during spring tides, increasing offshore advection (i.e., Helcogrammoides chilensis, Palacios-Fuentes et al. 2014), whereas some species have long pelagic larval duration before settlement (up to 100 days in Hypsoblennius sordidus, and up to 124 days in Scartichthys viridis, Mansur et al. 2014). The distributions of Blenniidae and Gobiidae larvae around Medes Islands in the Mediterranean Sea show that they were collected not only inshore but also over the continental shelf at a considerable distance from the habitats of the adults of these species (Sabatés et al. 2003). Similarly, larval 
03 January 2013

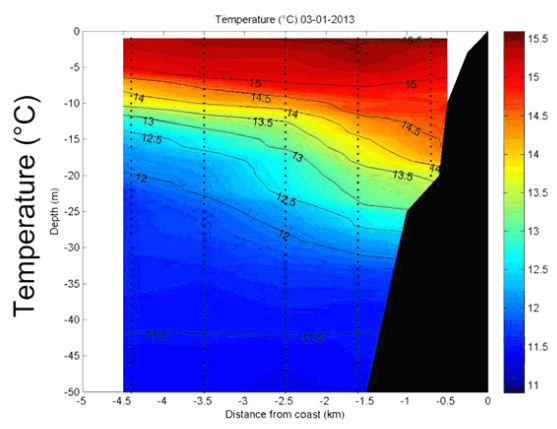

Saninty 03-01-2013

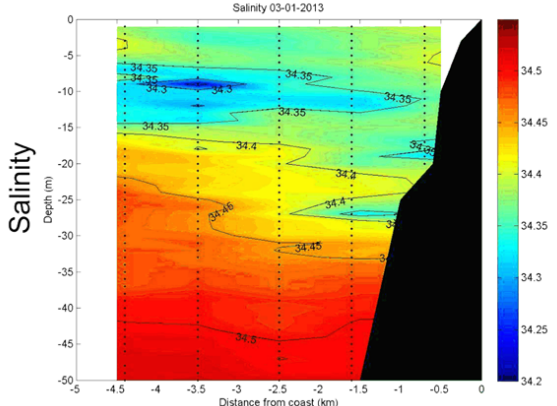

Density o, (Kg" $\left.\mathrm{m}^{3}\right)$ 03-01-2013

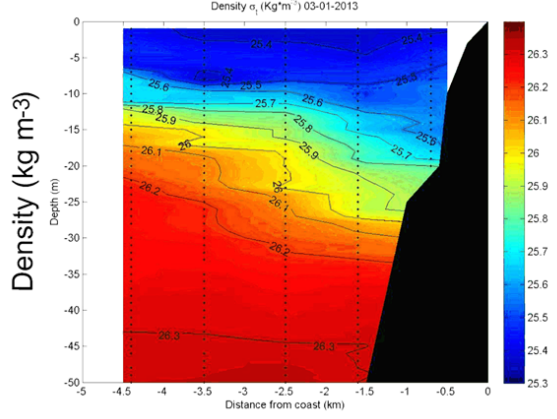

14 March 2013

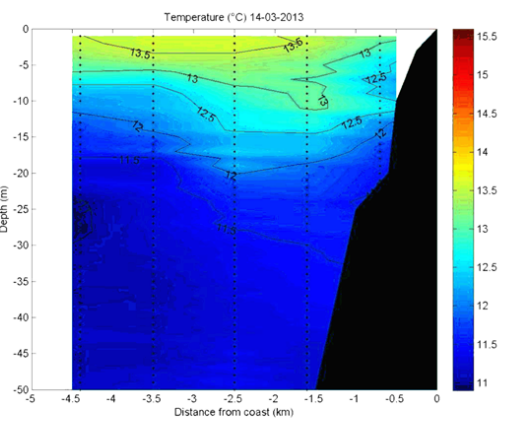

Selinty 14:03-2013

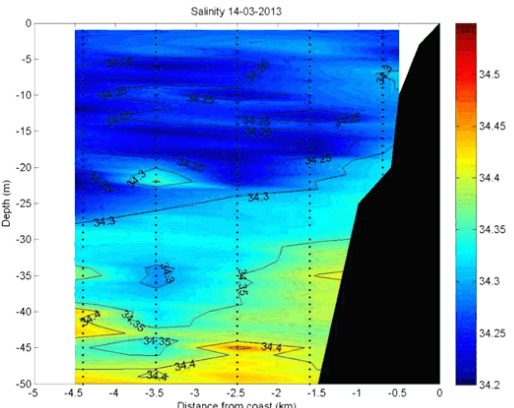

Density $\sigma_{1}\left(K^{9} m^{2} m^{3}\right) 1403-201$

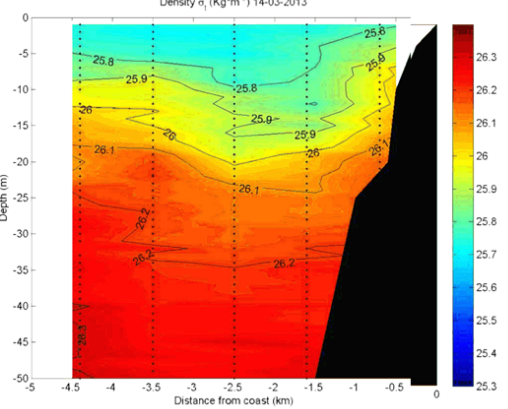

25 June 2013

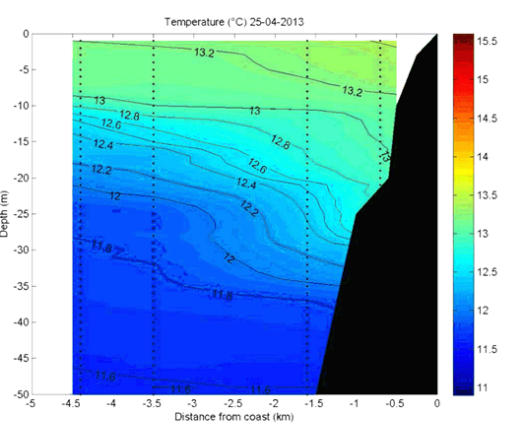

Salinity 25-04-2013

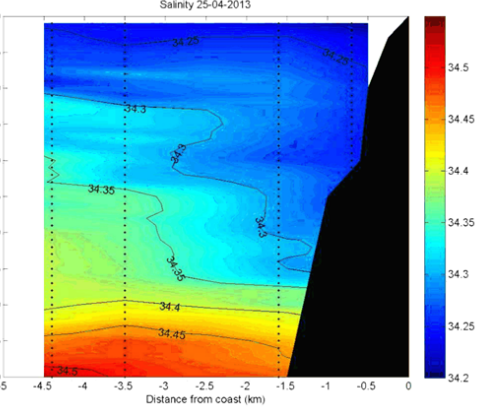

Density o, (Kg $\left.g^{*} \mathrm{~m}^{3}\right)$ 25-04-2013

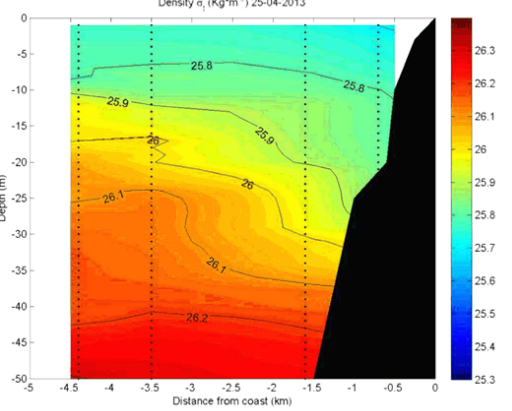

Figure 6. Cross-shelf vertical sections of temperature $\left({ }^{\circ} \mathrm{C}\right)$, salinity and density (units of sigma-t) for periods of high ectoparasite prevalence on fish larvae / Secciones verticales de temperatura $\left({ }^{\circ} \mathrm{C}\right.$ ), salinidad y densidad (unidades de sigma-t) para periodos de alta prevalencia de ectoparásitos en larvas de peces

H. chilensis and H. sordidus can be found in low abundance in slope waters ( $>10 \mathrm{~km}$ offshore) off the Chilean coast during spring and winter (Landaeta et al. 2008). In our study, the larvae of some species with $\mathrm{BB}$, such as blenny $S$. viridis and the damselfish Chromis crusma were highly abundant; however, they did not have ectoparasites. Most of the larvae of both species were collected as yolk-sac and small preflexion larvae, and they were mostly collected at $2 \mathrm{~km}$ offshore. Small larval size and/or development as well as reduced abundance in nearshore waters may preclude copepod infestation in these fish species. From a parasitological perspective, vagrant fish larvae may be lost for the source population and their potential ectoparasites will not be able to attach to their definitive host.
Recently, Palacios-Fuentes et al. (2015) described ectoparasites of a larval fish assemblage from El Quisco, central Chile, during late winter-early spring 2010-2012. Similarly to the results in this work, they found that larval clingfish G. marmoratus and triplefin $H$. cunninghami had the highest prevalence of pennellid ectoparasites, 12.16 and $5.27 \%$, respectively, and that G. marmoratus was the only host species that exhibited positive correlations with pennellid copepod burdens (i.e., prevalence and intensity). Although the larvae of this clingfish were not the most abundant with BB off Montemar during the studied period, their larvae were abundant in nearshore waters were pennellid copepodites may infest fish larvae. Features such as hatching during neap tides, reduced pelagic period (Contreras et al. 
2013) and nearshore aggregation aided by oceanographic conditions (this study) may enhance the chance of survival of the ectoparasite, and reaching a definitive host (demersal adult fishes from the subtidal zones) (Oliva \& González 2004).

Although common sardine larvae, S. bentincki were highly abundant from spring 2013 to the end of the study period, they did not have ectoparasites. Herrera (1990) described caligid ectoparasites on larval anchovy E. ringens. These ectoparasites are scarcely found in fish larvae with PS, however. This can be explained because it would reduce chances of the completion of the life cycle of ectoparasite copepods, decreasing the probability for the later to find a definitive host (Cribb et al. 2000). Larval stages of marine fish species with PS can be found in surface waters over the entire continental shelf off central Chile; this is due to species-specific reproductive tactics (spawning inside embayments, Landaeta \& Castro 2006, Landaeta et al. 2010), the effect of mesoscale oceanographic features such as upwelling events (Landaeta et al. 2008), river plumes (SotoMendoza et al. 2010) and/or ecophysiological processes (gas bladder inflation, Landaeta \& Castro 2013). Furthermore, eggs and larvae from PS may be transported onshore by north wind events during austral winter (Castro et al. 2000).

The definitive hosts for pennellids are benthic fish (Muñoz et al. 2015, Palacios-Fuentes et al. 2015), therefore, fish larvae with BB could be more exposed to larvae of parasitic copepods than fish with PS. In this sense, some oceanographic features may enhance parasite transmission to fish larvae from benthic habitats. For example, a shallow pycnocline might help the aggregation of planktonic organisms in regions where flow often reverses direction, resulting in reduced horizontal transport for the individual (Woodson \& McManus 2007). It seems plausible that ectoparasite infestation might increase in locations with these oceanographic conditions.

Nearshore environments of central Chile are characterized by intrusion of river plumes (Soto-Mendoza et al. 2010), which produces large turbidity in the system (Saldías et al. 2012), affecting the accumulation of meroplankton in the inner shelf (Vargas et al. 2006). Additionally, alongshore variation in upwelling intensity and the formation of warmwater pockets or upwelling shadows in sections of the coast (Wieters et al. 2003) may increase coastal retention of fish larvae and ectoparasite infestation. However, it is important to continue field-based as well as start laboratory-rearing studies to establish the real importance of oceanographic features in the process of host infestation of pennellid/caligid copepodites on fish larvae and juveniles from rocky shores, and their impact in the ecology (feeding, growth, survival) of early life stages of marine fishes.

In summary, larval fishes of species with benthic brooding, such as clingfish Gobiesox marmoratus and the triplefin Helcogrammoides cunninghami showed decreasing abundance with distance from the coast. Similarly, parasitized fish larvae were almost exclusively collected in nearshore waters. The most prevalent ectoparasites were pennellid copepods (Trifur spp.), which were found mainly on fish larvae originated from benthic brooding. Finally, during the sampling, the seawater was vertically stratified with a cross-shelf deepening (autumn-winter) or shoaling (summer) of the pycnocline from offshore to nearshore. This might contribute to both larval fish coastal retention as well as ectoparasite infestation in nearshore waters.

\section{ACKNOWLEDGMENTS}

We appreciate the field work of Jorge E. Contreras, Camilo Rodríguez-Valentino, David Ortiz, Marcos Morales-Lagos, Javier Vera-Duarte, among many, whom helped in the collection of physical and biological data during the coastal surveys. Three anonymous reviewers improved an early version of the manuscript. This manuscript was funded by Comisión de Ciencia y Tecnología (CONICYT) of the Chilean government, grant $n^{\circ} 1120868$ to GM, MFL and M. Teresa González, and Facultad de Ciencias del Mar y de Recursos Naturales (FACIMAR), Universidad de Valparaíso, Chile.

\section{LITERATURE CITED}

Balbontín F \& MC Orellana. 1983. Descripción de las larvas de pez linterna Hygophum bruuni del área de Valparaíso, Chile (Pisces, Myctophidae). Revista de Biología Marina 19: 205-216.

Balbontín F \& R Pérez. 1979. Modalidad de postura, huevos y estados larvales de Hypsoblennius sordidus (Bennett) en la Bahía de Valparaíso (Blenniidae: Perciformes). Revista de Biología Marina 16: 311-318.

Balbontín F \& R Pérez. 1980. Descripción de los estados larvales de Normanichthys crockeri Clark (Perciformes: Normanichthyidae) del área de Valparaíso, Chile. Revista de Biología Marina 17: 81-95.

Borges R, R Ben-Hamadou, MA Chícharo, P Ré \& EJ Gonçalves. 2007. Horizontal spatial and temporal distribution patterns of nearshore larval fish assemblages at a temperate rocky shore. Estuarine, Coastal and Shelf Science 71: 412-428.

Bush AO, KD Lafferty, JM Lotz \& AW Shostaka. 1997. Parasitology meets ecology on its own terms: Margolis et al. revisited. Journal of Parasitology 83: 575-583. 
Bustos CA, MF Landaeta \& F Balbontín. 2008. Efectos ambientales sobre la variabilidad espacial del ictioplancton de Chile austral durante noviembre de 2005. Revista Chilena de Historia Natural 81: 205-219.

Carassou L, D Ponton, C Mellin \& R Galzin. 2008. Predicting the structure of larval fish assemblages by a hierarchical classification of meteorological and water column forcing factors. Coral Reefs 27: 867-880.

Castro LR, GR Salinas \& EH Hernández. 2000. Environmental influences on winter spawning of the anchoveta Engraulis ringens off central Chile. Marine Ecology Progress Series 197: 247-258.

Contreras JE, MF Landaeta, G Plaza, FP Ojeda \& CA Bustos. 2013. The contrasting larval hatching patterns and larval growth of two sympatric clingfishes inferred by otolith microstructure analysis. Marine and Freshwater Research 64: 157-167.

Cribb TH, S Pichelin, V Dufour, RA Bray, C Chauvet, E Faliex, R Galzin, CM Lo, A Lo-Yat, S Morand, MC Rigny \& P Sasal. 2000. Parasites of recruiting coral reef fish larvae in New Caledonia. International Journal of Parasitology 30: 1445-1451.

Flores-Coto C, L Sanvicente-Añorve, F Zavala-García, J Zavala-Hidalgo \& R Funes-Rodríguez. 2014. Environmental factors affecting structure and spatial patterns of larval fish assemblages in the southern Gulf of Mexico. Revista de Biología Marina y Oceanografía 49: 307-321.

Harris SA, DP Cyrus \& LE Beckley. 1999. The larval fish assemblage in nearshore coastal waters off the St. Lucia Estuary, South Africa. Estuarine, Coastal and Shelf Science 49: 789-811.

Hernández-Miranda E, AT Palma \& FP Ojeda. 2003. Larval fish assemblages in nearshore coastal waters off central Chile: temporal and spatial patterns. Estuarine, Coastal and Shelf Science 56: 1075-1092.

Herrera G. 1984a. Parasitismo de juveniles de copépodos caligoideos sobre larvas de peces de la Bahía Coliumo (36 32'S; 75 57’ W), Chile. Biología Pesquera 13: 31-38.

Herrera G. 1984b. Descripción de estados post-embrionales de Ophiogobius jenynsi Hoese 1976 (Gobiidae, Blennioidei). Revista de Biología Marina 20: 159-168.

Herrera G. 1990. Incidence of larval anchovy, Engraulis ringens, parasitized by caligid developmental stages. Bulletin of Marine Science 47: 571-575.

Herrera GA, A Llanos-Rivera \& MF Landaeta. 2007. Larvae of the sand stargazer Sindoscopus australis and notes on the development of Dactyloscopidae (Perciformes: Blennioidei). Zootaxa 1401: 63-68.

Kent J, G Jenkins \& S Acevedo. 2013. Temporal and spatial patterns in ichthyoplankton assemblages in bay and open coastal environments. Journal of Fish Biology 82: 408429.
Landaeta MF \& LR Castro. 2006. Spawning and larval survival of the Chilean hake Merluccius gayi under later summer conditions in the Gulf of Arauco, central Chile. Fisheries Research 77: 115-121.

Landaeta MF \& LR Castro. 2013. Vertical distribution and gas bladder inflation/deflation in postlarval anchoveta Engraulis ringens during upwelling events. Journal of the Marine Biological Association of the United Kingdom 93: 321-331.

Landaeta MF, GA Herrera, M Pedraza, CA Bustos \& LR Castro. 2006. Reproductive tactics and larval development of bigeye flounder, Hippoglossina macrops, off central Chile. Journal of the Marine Biological Association of the United Kingdom 86: 1253-1264.

Landaeta MF, R Veas, J Letelier \& LR Castro. 2008. Larval fish assemblages off central Chile upwelling ecosystem. Revista de Biología Marina y Oceanografía 43: 569-584.

Landaeta MF, K Schrebler, CA Bustos, J Letelier \& F Balbontín. 2009. Temporal fluctuations of nearshore ichthyoplankton off Valparaíso, central Chile, during the ENSO cycle 1997-2000. Revista de Biología Marina y Oceanografía 44: 571-582.

Landaeta MF, PA Inostroza, A Ramírez, S Soto-Mendoza \& LR Castro. 2010. Distribution patterns, larval growth and hatch dates of early stages of the mote sculpin Normanichthys crockeri (Scorpaeniformes, Normanichthyidae) in the upwelling ecosystem off central Chile. Revista de Biología Marina y Oceanografía 45: 575588.

Lee O, RDM Nash \& BS Danilowicz. 2005. Small-scale spatio-temporal variability in ichthyoplankton and zooplankton distribution in relation to a tidal-mixing front in the Irish Sea. ICES Journal of Marine Science 62: 10211036.

Mansur L, G Plaza, MF Landaeta \& FP Ojeda. 2014. Planktonic duration in fourteen species of intertidal rocky fishes from the south-eastern Pacific Ocean. Marine and Freshwater Research 65: 901-909.

Muhling BA, RH Smith, L Vásquez-Yeomans, JT Lamkin, EM Jones, L Carrillo, E Sosa-Cordero \& E Malca. 2013. Larval fish assemblages and mesoscale oceanographic structure along the Mesoamerican Barrier Reef System. Fisheries Oceanography 22: 409-428.

Muñoz G, MF Landaeta, P Palacios-Fuentes, Z López \& MT González. 2015. Parasite richness in fish larvae from the nearshore waters of central and northern Chile. Folia Parasitologica 62: 029. <doi: 10.14411/fp.2015.029>

Navarrete-Fernández T, MF Landaeta, CA Bustos \& A Pérez-Matus. 2014. Nest building and description of parental care behavior in a temperate reef fish, Chromis crusma (Pisces: Pomacentridae). Revista Chilena de Historia Natural 87: 30. <doi:10.1186/s40693-014-0030-2> 
Oliva ME \& MT González. 2004. Metazoan parasites of Sebastes capensis from two localities in northern Chile as tools for stock identification. Journal of Fish Biology 64(1): 170-175.

Orellana MC \& F Balbontín. 1983. Estudio comparativo de las larvas de Clupeiformes de la costa de Chile. Revista de Biología Marina 19(1): 1-46.

Palacios-Fuentes P, MF Landaeta, G Muñoz, G Plaza \& FP Ojeda. 2012. The effects of a parasitic copepod on the recent larval growth of a fish inhabiting rocky coasts. Parasitology Research 111: 1661-1671.

Palacios-Fuentes P, MF Landaeta, N Jahnsen-Guzmán, G Plaza \& FP Ojeda. 2014. Hatching patterns and larval growth of a triplefin from central Chile inferred by otolith microstructure analysis. Aquatic Ecology 48: 259-266.

Palacios-Fuentes P, MF Landaeta, MT González, G Plaza, FP Ojeda \& G Muñoz. 2015. Is ectoparasite related to host density? Evidence from nearshore fish larvae off the coast of central Chile. Aquatic Ecology 49: 91-98.

Pérez R. 1979. Desarrollo postembrionario de Trypterigion chilensis Cancino 1955, en la Bahía de Valparaíso (Tripterygiidae: Perciformes). Revista de Biología Marina 16(3): 319-329.

Pérez R. 1981. Desarrollo embrionario y larval de pejesapos Sicyases sanguineus y Gobiesox marmoratus en la Bahía de Valparaíso, Chile, con notas sobre su reproducción (Gobiesocidae: Pisces). Investigaciones Marinas 9: 1-24.

Plaza G, MF Landaeta, CV Espinoza \& FP Ojeda. 2013. Daily growth patterns of six species of young-of-the-year of Chilean intertidal fishes. Journal of the Marine Biological Association of the United Kingdom 93(2): 389-395.

Sabatés A, M Zabala \& A García-Rubies. 2003. Larval fish communities in the Medes Islands Marine Reserve (Northwest Mediterranean). Journal of Plankton Research 25(9): 1035-1046.
Saldías GS, M Sobarzo, J Largier, C Moffat \& R Letelier. 2012. Seasonal variability of turbid river plumes off central Chile based on high-resolution MODIS imagery. Remote Sensing of Environment 123: 220-233.

Sánchez-Velasco L, MF Lavín, SPA Jiménez-Rosenberg, VM Godínez, E Santamaría-del-Angel \& DU HernándezBecerril. 2013. Three-dimensional distribution of fish larvae in a cyclonic eddy in the Gulf of California during the summer. Deep-Sea Research I 75: 39-51.

Soto-Mendoza S, LR Castro \& A Llanos-Rivera. 2010. Variabilidad espacial y temporal de huevos y larvas de Strangomera bentincki y Engraulis ringens, asociados a la desembocadura del río Itata, Chile. Revista de Biología Marina y Oceanografía 45(3): 471-487.

Su W-C, W-T Lo, D-C Liu, L-J Wu \& H-Y Hsieh. 2011. Larval fish assemblages in the Kuroshio waters east of Taiwan during two distinct monsoon seasons. Bulletin of Marine Science 87(1): 13-29.

Vargas CA, DA Narváez, A Piñones, SA Navarrete \& NA Lagos. 2006. River plume dynamics influences transport of barnacle larvae in the inner shelf off central Chile. Journal of the Marine Biological Association of the United Kingdom 86: 1057-1065.

Wieters E, DM Kaplan, SA Navarrete, A Sotomayor, J Largier, KJ Nielsen \& F Véliz. 2003. Alongshore and temporal variability in chlorophyll $a$ concentration in Chilean nearshore waters. Marine Ecology Progress Series 249: 93-105.

Woodson CB \& MA McManus. 2007. Foraging behavior can influence dispersal of marine organisms. Limnology and Oceanography 52(6): 2701-2709.

Zúñiga HN \& ES Acuña. 1992. Larval development of two sympatric flounders, Paralichthys adspersus (Steindachner, 1867) and Paralichthys microps (Gunther, 1881) from the Bay of Coquimbo, Chile. Fishery Bulletin 90: 607-620. 